\title{
Fc gamma receptors: glycobiology and therapeutic prospects
}

This article was published in the following Dove Press journal:

Journal of Inflammation Research

16 November 2016

Number of times this article has been viewed

\section{Jerrard M Hayes' \\ Mark R Wormald ${ }^{2}$ \\ Pauline M Rudd ${ }^{3}$ \\ Gavin P Davey'}

'School of Biochemistry and Immunology, Trinity Biomedical Sciences Institute, Trinity College, Dublin, Ireland; ' ${ }^{2}$ Department of Biochemistry, Oxford Glycobiology Institute, University of Oxford, Oxford, UK; ${ }^{3}$ NIBRT Glycoscience Group, National Institute for Bioprocessing, Research and Training, Dublin, Ireland
Correspondence: Jerrard M Hayes School of Biochemistry and Immunology, Trinity Biomedical Sciences Institute, Trinity College, Dublin 2, Ireland

Tel +353 I 963527

Email jehayes@tcd.ie
Abstract: Therapeutic antibodies hold great promise for the treatment of cancer and autoimmune diseases, and developments in antibody-drug conjugates and bispecific antibodies continue to enhance treatment options for patients. Immunoglobulin (Ig) $\mathrm{G}$ antibodies are proteins with complex modifications, which have a significant impact on their function. The most important of these modifications is glycosylation, the addition of conserved glycans to the antibody Fc region, which is critical for its interaction with the immune system and induction of effector activities such as antibody-dependent cell cytotoxicity, complement activation and phagocytosis. Communication of IgG antibodies with the immune system is controlled and mediated by Fc gamma receptors (Fc $\gamma R s)$, membrane-bound proteins, which relay the information sensed and gathered by antibodies to the immune system. These receptors are also glycoproteins and provide a link between the innate and adaptive immune systems. Recent information suggests that this receptor glycan modification is also important for the interaction with antibodies and downstream immune response. In this study, the current knowledge on Fc $\gamma \mathrm{R}$ glycosylation is discussed, and some insight into its role and influence on the interaction properties with IgG, particularly in the context of biotherapeutics, is provided. For the purpose of this study, other Fc receptors such as Fc $\alpha$ R, FceR or FcRn are not discussed extensively, as IgG-based antibodies are currently the only therapeutic antibody-based products on the market. In addition, Fc $\gamma$ Rs as therapeutics and therapeutic targets are discussed, and insight into and comment on the therapeutic aspects of receptor glycosylation are provided.

Keywords: glycosylation, IgG, Fc gamma receptor, therapeutic monoclonal antibody

\section{Therapeutic antibodies and glycosylation}

Antibodies or immunoglobulins (Igs) are important components of the humoral immune system, which act as surveyors, sensing pathogens and transformed cells, communicating this information to the innate and adaptive immune systems. IgG antibodies provide the first line of defense against invading microorganisms, and due to their ability to detect tumor-associated antigens and neutralize inflammatory mediators such as tumor necrosis factor (TNF)- $\alpha$ this class of antibodies has been used with great success in treatments for cancer and autoimmunity conditions. Therapeutically, all the current monoclonal antibodies (Mabs) and Mab fusion proteins used in autoimmune diseases, inflammatory conditions and oncology use the IgG backbone. This is the most studied and best characterized of the Igs and is divided into four distinct subclasses (IgG1, IgG2, IgG3, IgG4), each with differences in sequence and structure, binding properties to cellular Fc gamma receptors (Fc $\gamma$ Rs) and effector functions (Figure 1). ${ }^{1,2}$ Mab therapy was born in the 1970s with the major discoveries of the IgG structure by Edelman et $\mathrm{al}^{3}$ 


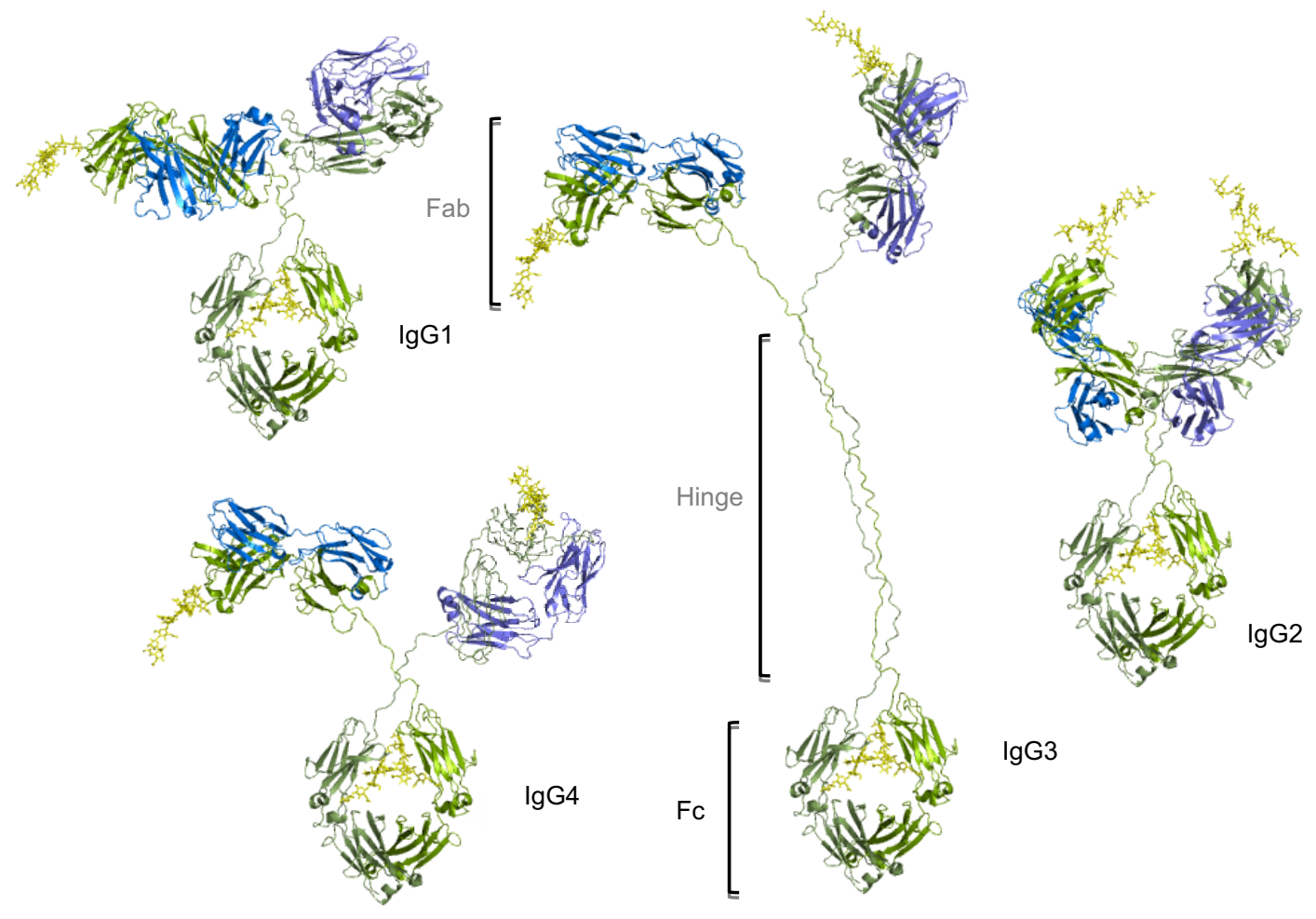

Figure I The IgG subtypes.

Notes: Four subtypes of $\lg G$ exist in humans: $\lg G I, \lg G 2$, $\lg G 3$, $\lg G 4$, each with differences in sequence, structure, glycosylation and communication with Fc $\gamma$ Rs. The four subtypes are named based on their respective abundance in serum with IgGI being the most abundant. IgG antibodies consist of two Fab regions that can bind both an antigen molecule and the Fc region which interact with the FcyR, joined by a highly flexible hinge region. IgG has a longer hinge region than the other IgG subtypes. Each IgG subtype has conserved Asn 297 amino acids in the Fc region with $\mathrm{N}$-glycans attached (shown in yellow). Typically, the Fc glycans are bi-antennary galactosylated structures with varying amounts of core fucosylation and sialylation. Glycosylation is also found in the Fab regions with higher proportions of galactosylated and sialylated glycans. Heavy chains are shown in green, and light chains are shown in blue and purple.

Abbreviations: Fab, fragment antigen binding; Fc $\gamma R$, Fc gamma receptor; $\lg G$, immunoglobulin $G$.

and Porter ${ }^{4}$ and the development of hybridoma technology by Kohler and Milstein. ${ }^{5}$ Initially, Mab therapeutics were murine in nature, leading to significant problems such as inadequate serum retention, induction of IgE-specific allergic reactions and anaphylaxis due to the presence of murine-derived gal $\alpha(1,3)$-gal and $\mathrm{N}$-glycolylneuraminic acid glycan epitopes and failure to induce effector responses through impaired interaction with human Fc $\gamma$ Rs. ${ }^{6}$ Developments in recombinant antibody technology and the production of chimeric, humanized and fully human antibodies have addressed many of these issues, most importantly the humanization of glycosylation to ensure productive interaction with Fc $\gamma$ Rs and prevention of anaphylaxis.

Glycans play an important role in IgG-mediated immunity, and crucially IgG-based therapeutics typically have glycan attributes that influence the interaction with Fc $\gamma R s$ and downstream immune response. ${ }^{7-10}$ Therefore, glycans are important factors in the design of IgG-based therapeutics, particularly in the $\mathrm{Fc}$ region, which mediates the effector responses induced by $\mathrm{IgG}$, as well as recycling and the anti-inflammatory activity of $\operatorname{IgG}^{2,11,12}$ Currently, the most important of these appears to be the $\alpha(1,6)$-linked core fucose, which has been the subject of intensive pharmaceutical interest since it was discovered that IgG lacking this glycan characteristic had enhanced binding to activating Fc $\gamma$ Rs and improved antibody-dependent cell cytotoxicity (ADCC). ${ }^{13-18}$ The market approval of the glycoengineered form of the anti-CD20 Mab Gazyra (Genentech, San Francisco, CA, USA) with reduced core fucosylation highlights the success of this strategy (comprehensive reviews on the biopharmaceutical and therapeutic antibody markets are discussed by Walsh ${ }^{19}$ and Ecker et $\mathrm{al}^{20}$ ). Terminal sialylation and mannosylation of antibody $\mathrm{N}$-glycans are also important functional features of antibodies, which significantly impact their activity and serum retention. A high sialic acid content has been proposed to impact the IgG Fc structure and force it to acquire a closed conformation resulting in decreased binding to Fc $\gamma R$ s; however, X-ray crystallographic data suggest that this is not the case, and no major Fc structural alterations were observed with increased sialylation..$^{21,22}$ Sialylation can also impact the clearance rates of therapeutic antibodies with higher sialylation leading to longer serum retention times ${ }^{23,24}$ 
and induction of the anti-inflammatory effects of intravenous immunoglobulin (IVIg). ${ }^{12,25}$ Terminal mannosylation, usually in the form of hypogalactosylated glycans (G0, G1), can also affect the serum retention of antibodies and binding to mannose-binding lectin (MBL) on macrophages. ${ }^{26,27}$ The glycan attributes of potential Mab therapeutics must therefore be carefully considered as the binding to cellular FcyRs, activation of the complement cascade and phagocytosis, serum retention, recycling and placental transport of the therapeutic can be greatly influenced by the Fc glycans.

\section{FcyRs: the key to IgG biological activity}

Emerging from the success of Mab therapy and glycoengineering is the importance of FcyRs for their success and therapeutic efficacy and the vast complexity in receptor biology. Therapeutically, FcyRs were once utilized solely for analyzing the efficacy and safety of therapeutic Mabs through biophysical binding experiments; however, this is no longer the case and these antibody receptors are now realizing their potential as anti-inflammatory therapies and in autoimmune conditions. IgG antibodies survey and communicate the information sensed to the immune system via interaction with these single-pass transmembrane receptors of the Ig superfamily. The family of receptors that are found almost ubiquitously throughout the body, from myeloid cells to lymphoid and neuronal cells, are broadly characterized into three groups: Fc $\gamma$ RI, Fc $\gamma$ RII and Fc $\gamma$ RIII. ${ }^{28}$ Differences exist between the groups of receptors, particularly in their structure, function, glycosylation and affinity for IgG. ${ }^{28-33}$

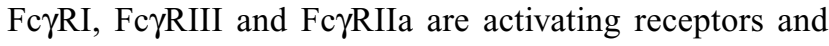
induce effector activities in innate effector cells such as macrophages and natural killer (NK) cells. FcyRIIb is fundamentally different from the other activating receptors and acts as an inhibitory receptor. Signaling through this receptor induces inhibitory signals that decrease the activation/inhibition (A/I) ratio and bring the cells further from the threshold level required for activation. ${ }^{34}$

Extensive variability at the genomic, transcriptomic and proteomic level exists among the human Fc $\gamma \mathrm{Rs}$, with multiple genes, transcripts, polymorphic variants and glycovariants adding to the complexity of these receptors. Polymorphic variants have been found for nearly all of the FcyRs, with significant effects on the interaction with IgG and downstream physiological response. ${ }^{35-38}$ Multimerization of antibodies and antigen and engagement of Fc $\gamma \mathrm{Rs}$ lead to microclustering of receptors in the plasma membrane and activation of signaling cascades involving immunoreceptor tyrosine-based activation motif and immunoreceptor tyrosine-based inhibitory motif resulting in cellular activation or inhibition, activities that can be influenced by the glycosylation state and polymorphic variant of the receptor. It is also important to note that due to the high-affinity nature of Fc $\gamma \mathrm{RI}$, it is believed to be constantly bound by monomeric IgG and it is the lower affinity receptor that participates in many of the proinflammatory activities of Fc $\gamma$ Rs. In addition, when Mabs are used therapeutically, due to the very high serum concentration of $\operatorname{IgG}(\sim 15 \mathrm{mg} / \mathrm{mL})$, practically all of the cellular Fc $\gamma \mathrm{Rs}$ will be occupied and therefore higher concentrations of a therapeutic antibody are required, further increasing the need for glycoengineered antibodies with higher $\mathrm{Fc} \gamma \mathrm{R}$ affinities than serum IgG.

\section{Glycobiology of FcyRs}

Glycosylation research into Fc $\gamma$ Rs began over 30 years ago, but still currently relatively little is known about how these receptors are glycosylated by cells of the immune system, in healthy and disease states (a review of Fc receptors and glycosylation is discussed by Hayes et $\mathrm{al}^{39}$ ). Several recent structural and biophysical studies have pointed to important roles of Fc $\gamma \mathrm{R}$ glycosylation and have implicated it in the binding mechanism with IgG. ${ }^{40-43}$ The vast majority of glycan data and glycosylation information that is available is for the activating Fc $\gamma$ RIIIa receptor, mainly due to its role in NK cell-mediated ADCC and its therapeutic relevance and importance to the pharmaceutical industry. Glycosylation, however, varies widely between the different receptors with different numbers of glycosylation sites and differential and cell type-specific glycosylation patterns (Tables 1 and 2; Figure 2). Seminal work by Edberg et al, ${ }^{44}$ Edberg and Kimberley ${ }^{45}$ and Kimberly et $\mathrm{al}^{46}$ showed that Fc $\gamma$ RIIIa exists as cell type-specific glycoforms on monocytes and macrophages with different affinities for IgG and different responses to an IgG stimulus due to the differently glycosylated Fc $\gamma$ Rs. This has intriguing implications for how immune cells respond to $\mathrm{IgG}$ based on the glycosylation status of the $\mathrm{Fc} \gamma \mathrm{R}$. Unfortunately, no further information on the natural glycosylation on these receptors exists in the literature, and there is therefore a lack of information regarding these receptors and the cellular activation or inhibition by $\mathrm{IgG}$. The A/I ratio, for example, is likely to be skewed toward activation or inhibition depending on how a particular cell glycosylates its Fc $\gamma R s$ in healthy and disease states. This also has important implications for the biopharmaceutical industry, and response to Mab therapy in patients may depend on how their Fc $\gamma$ Rs are glycosylated. 
Table I Properties of human FcyRs

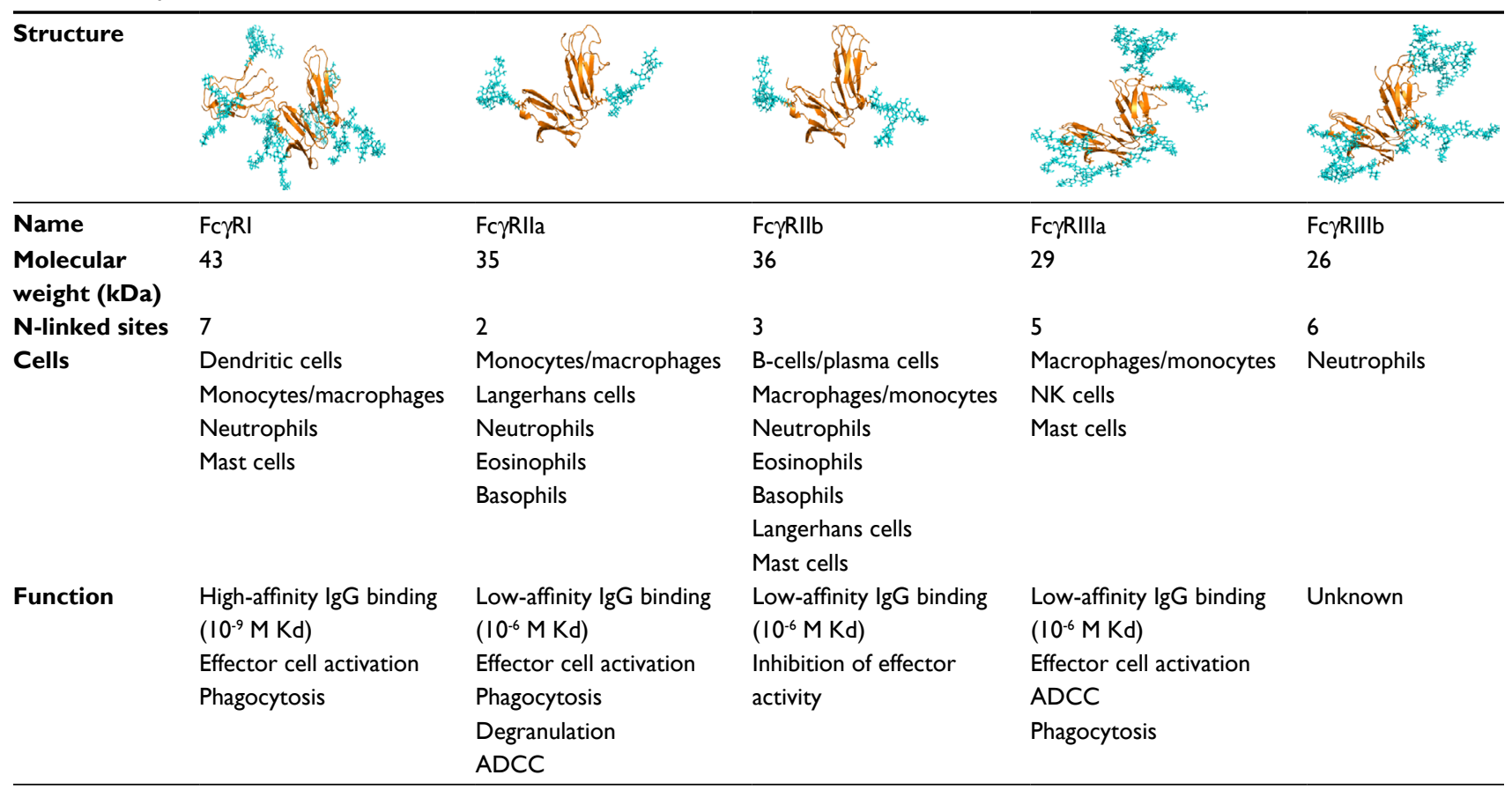

Abbreviations: ADCC, antibody-dependent cell cytotoxicity; FcyR, Fc gamma receptor; lgG, immunoglobulin G; NK, natural killer.

Table 2 Annotation of human FcyR glycosylation showing position and conservation of $\mathrm{N}$-glycan sites

\begin{tabular}{|c|c|c|c|c|c|}
\hline Fc $\gamma$ RI numbering & FcyRI & FcyRIIa & FcyRIIb & Fc $\gamma$ RIIIa & FcyRIIIb \\
\hline \multicolumn{6}{|l|}{ Domain I } \\
\hline 52 & - & - & - & $\checkmark$ & $\checkmark$ \\
\hline 59 & $\checkmark$ & - & - & $\checkmark$ & $\checkmark$ \\
\hline 78 & $\checkmark$ & $\checkmark$ & $\checkmark$ & - & $\checkmark$ \\
\hline 88 & - & - & - & $\checkmark$ & $\checkmark$ \\
\hline \multicolumn{6}{|l|}{ Domain 2} \\
\hline 152 & $\checkmark$ & - & - & - & - \\
\hline 159 & $\checkmark$ & $\checkmark$ & $\checkmark$ & - & - \\
\hline 163 & $\checkmark$ & - & - & - & - \\
\hline 175 & - & - & - & $\checkmark$ & $\checkmark$ \\
\hline 182 & - & - & - & $\checkmark$ & $\checkmark$ \\
\hline \multicolumn{6}{|l|}{ Domain 3} \\
\hline 195 & $\checkmark$ & na & na & na & na \\
\hline 240 & $\checkmark$ & na & na & na & na \\
\hline
\end{tabular}

Notes: Annotation is based on three-dimensional structures and positions of glycan sites within the three-dimensional structures. The most conserved glycan site across the receptors is Asn 78, which is near the Fc binding site. The Asn 175 glycan site of FcyRIlla (Asn 162) is almost within the binding site and has been proposed to form carbohydrate-carbohydrate interactions with the $\mathrm{Fc}$ glycan. $\mathrm{N}$-glycosylation sites are named for Fc $\gamma \mathrm{RI}$ using the UniprotKB numbering scheme.

Abbreviation: Fc $\gamma$ R, Fc gamma receptor; na, not applicable.

More recently, high-resolution biophysical and structural data collection has revealed the importance of Fc $\gamma$ RIIIa glycosylation..$^{40,43,47}$ This low-affinity activating receptor is extremely homologous in its extracellular domain, in both amino acid sequence and three-dimensional structure to the related FcyRIIIb. ${ }^{48,49}$ Two N-linked sites of FcyRIIIa have been shown to regulate the binding of IgG; a glycan on Asn
45 has an inhibitory role and negative effect on IgG binding, whereas glycosylation at Asn 162, which is located at the IgGbinding interface in the three-dimensional structure, increases IgG interaction and binding affinity ${ }^{40-42}$ (Figure 3). Glycan analysis of Fc $\gamma$ RIIIa from recombinant systems followed by biophysical binding experiments showed that glycosylation is dependent on the source of the receptor and that specific glycans can be located on the Asn 162 site that influences and mediates IgG binding ${ }^{43,47,50}$ (Figure 3). Structural studies have also shown that on a molecular level a unique carbohydrate-carbohydrate interface exists between afucosylated IgG1 and Fc $\gamma$ RIIIa, which can explain the increase in affinity for therapeutic antibodies lacking core fucose. ${ }^{40}$

Human immune cells have different combinations of Fc $\gamma R s$ with different numbers of N-glycosylation sites (Table 1 and Table 2), and IgG immune complexes will interact with many different receptors on the same cell, creating an extremely complex series of interactions and signaling pathways/stimuli. Adding further complexity is the differential glycosylation of the FcyRs, which are found on the same cell. Previous studies have described the glycan compositions of recombinant Fc $\gamma R s$ (Fc $\gamma R I$, Fc $\gamma$ RIIa, Fc $\gamma$ RIIb, Fc $\gamma$ RIIIa and FcyRIIIb) from different sources and showed that the glycosylation is complex with multi-antennary structures and extensive outer-arm modifications (Figure 2). ${ }^{43,50-55}$ Fc $\gamma R$ I, which has seven potential N-glycosylation sites, is structurally different from the other receptors with an extra 

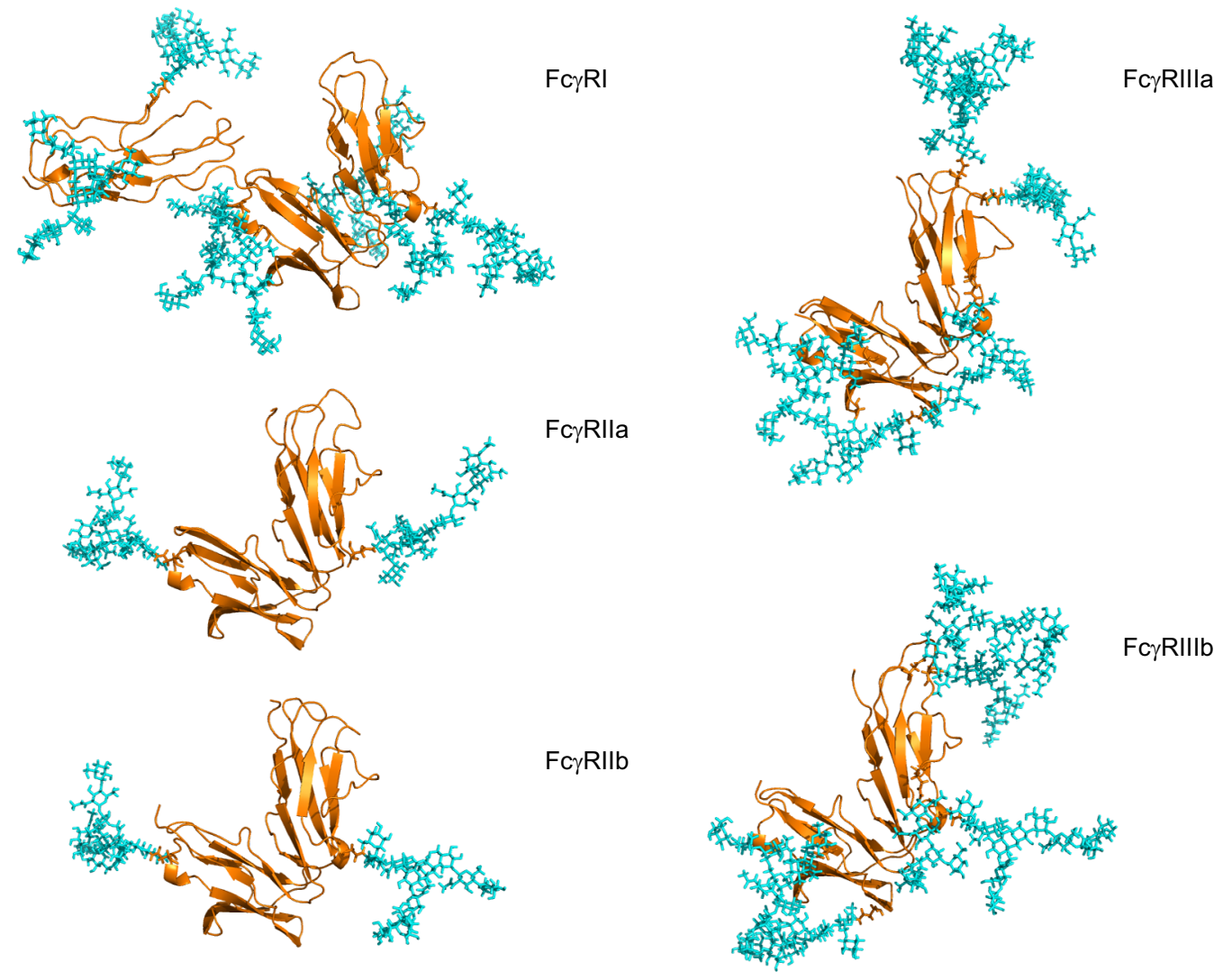

Figure 2 Human FcyRs are complex glycoproteins.

Notes: Fc $\gamma \mathrm{R}$ ectodomains were modeled with $\mathrm{N}$-glycans on each glycosylation site for each receptor, taking into account glycan size and composition, torsion angles and free energies. The N-glycans (shown in cyan) were modeled based on identified glycans from FcyRs (shown in gold) produced in recombinant systems such as NSO, CHO and HEK293 systems. ${ }^{43,47,50}$ In the case of FcyRllla, site-specific glycosylation studies were performed by Zeck et al, ${ }^{47}$ and this information was used to build the glycans shown on the Asn 162 site located at the binding interface with lgG. For the remaining receptors, no site-specific analysis was available, and in these cases the most abundant glycans identified from the recombinant sources were used to model $\mathrm{N}$-glycosylation for these receptors. Fc $\gamma \mathrm{RI}$ has an extra D3 domain, which contributes to its high-affinity nature, and this domain also contains two glycosylation sites. The glycan compositions modeled onto each $\mathrm{N}$-glycosylation site for each FcyR are named according to the Oxford notation (https://glycobase.nibrt.ie/glycobase/show_nibrt.action) ${ }^{86}$ and are as follows: FcyRl: Asn 59 (Man 5), Asn 78 (FA2G2SI), Asn 152 (FA2GN2S2), Asn I59 (Man 6),

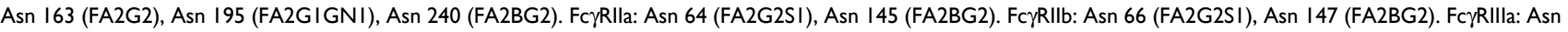
38 (FA2G2SI), Asn 45 (FA2G2), Asn 74 (FA4G4S4), Asn 162 (FA2G2), Asn 169 (FA2BG2). FcyRlllb: Asn 35 (FA2GalNAc2S2), Asn 42 (Man 5), Asn 61 (FA2G2SI), Asn 71

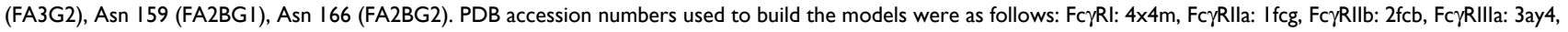
FcyRIIlb: le4j.

Abbreviations: Fc $\gamma R$, Fc gamma receptor; IgG, immunoglobulin G; PDB, Protein Data Bank.

D3 domain, which contributes to its high-affinity nature. ${ }^{56,57}$

There is little information available regarding the nature of Fc $\gamma R I$ glycosylation or the glycosylation site occupancy; however, studies performed on recombinant Fc $\gamma R$ I from NS0 and HEK293 cells showed that the receptor expressed significant amounts of high-mannose glycans and complex multi-antennary structures with large amounts of corefucosylation and outer-arm modifications; glycan monosaccharide compositions which can influence the IgG-binding interaction (Figures 3 and 4). ${ }^{43,50}$ Crystal structures of Fc $\gamma R \mathrm{R}$ are available, and recently a crystal structure in complex with IgG was described (Figure 3); however, even though the IgG glycans were shown to be important for the interaction, little information is available on the receptor glycans (Figures 3 and 4) ${ }^{58,59}$ Biologically and functionally Fc $\gamma$ RIIa and Fc $\gamma R I I b$ are significantly different as Fc $\gamma \mathrm{RIIb}$ is the inhibitory Fc $\gamma \mathrm{R}$; however, despite the biological differences, they demonstrate significant homology in their extracellular domains with $\sim 92 \%$ sequence identity. Data exist for the glycosylation of the receptors from NS0, HEK293, CHO and insect cells and demonstrate that the receptors display complex glycan structures with core fucosylation and minimal sialylation (Figure 2). ${ }^{43,50-52}$ In one report of glycosylation of Fc $\gamma$ RIIa from insect cells, sialylation was not detected and glycosylation was not reported to influence IgG binding. ${ }^{51}$ The only information on Fc $\gamma$ RIIb glycosylation comes from reports describing recombinant sources from NS0 and HEK293 cells, and similar to other Fc $\gamma$ Rs this receptor presents with multi-antennary structures, which are core fucosylated and undersialylated (Figure 2). ${ }^{43,50} \mathrm{Fc} \gamma \mathrm{Rs}$ have a number of glycan characteristics in common, all contain complex multi-antennary structures, which are core fucosylated and 

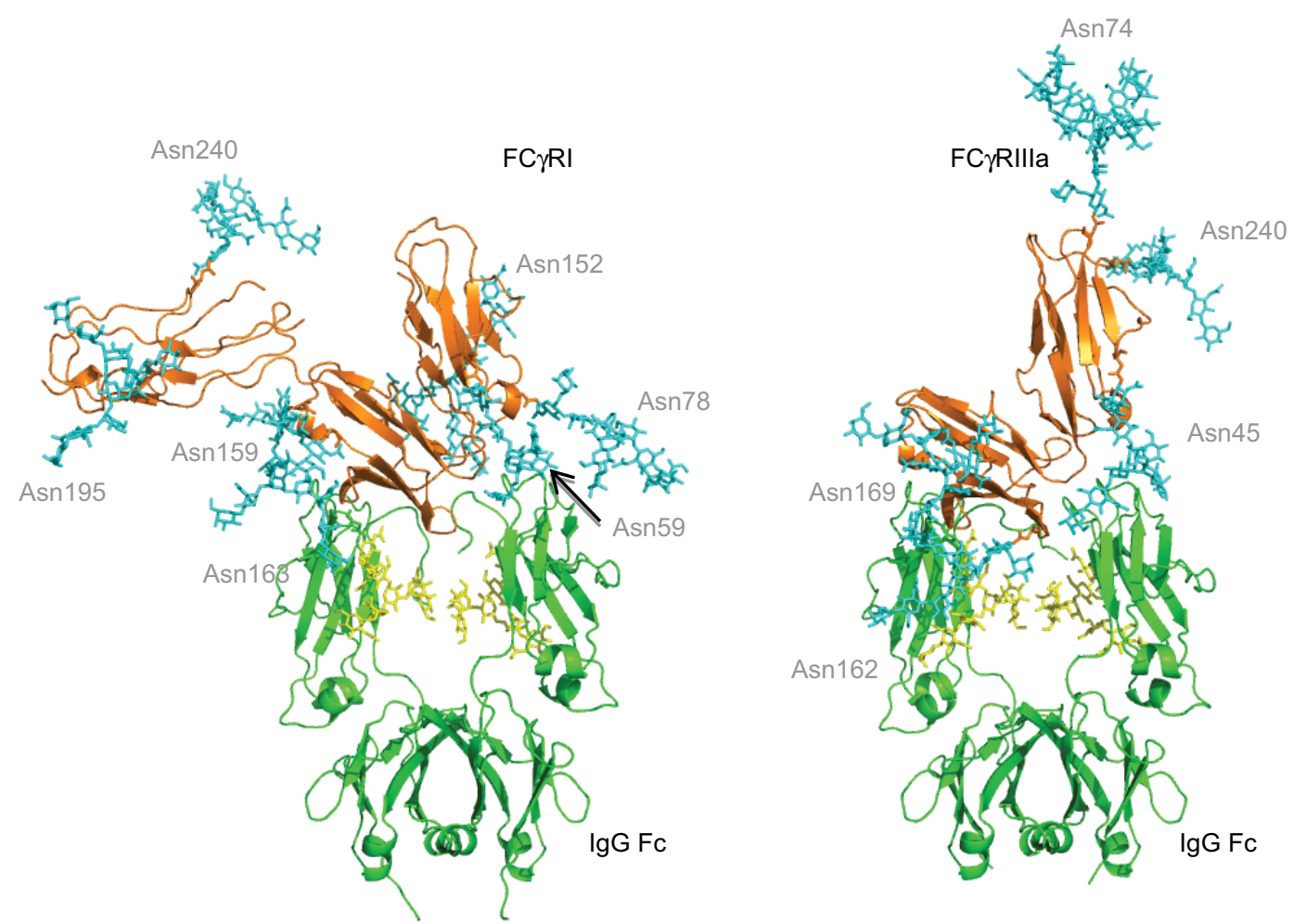

Figure $3 \mathrm{Fc} \gamma \mathrm{R}-\operatorname{lgG}$ complexes with modeled N-glycans show complexity of glycosylation and the potential roles of glycans in the binding interaction with lgG.

Notes: The Asn 162 glycan of FcyRllla has been shown to form carbohydrate-carbohydrate interactions with the bi-antennary glycan of lgG. ${ }^{40}$ This asparagine residue is

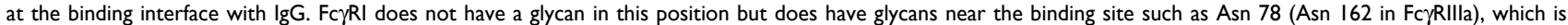
structurally conserved in each of the FcyRs. The glycan compositions modeled onto each $\mathrm{N}$-glycosylation site for each FcyR are named according to the oxford notation (see https://glycobase.nibrt.ie/glycobase/show_nibrt.action) ${ }^{86}$ and are as follows: FcrRI: Asn 59 (Man 5), Asn 78 (FA2G2SI), Asn I52 (FA2GN2S2), Asn I59 (Man 6), Asn I63 (FA2G2), Asn 195 (FA2GIGNI), Asn 240 (FA2BG2). FcrRIlla: Asn 38 (FA2G2SI), Asn 45 (FA2G2), Asn 74 (FA4G4S4), Asn I62 (FA2G2), Asn I69 (FA2BG2). PDB accession numbers used to build the models were as follows: FcyRI: $4 \times 4 \mathrm{~m}$, FcyRllla: 3 ay4.

Abbreviations: FçR, Fc gamma receptor; IgG, immunoglobulin G.

A

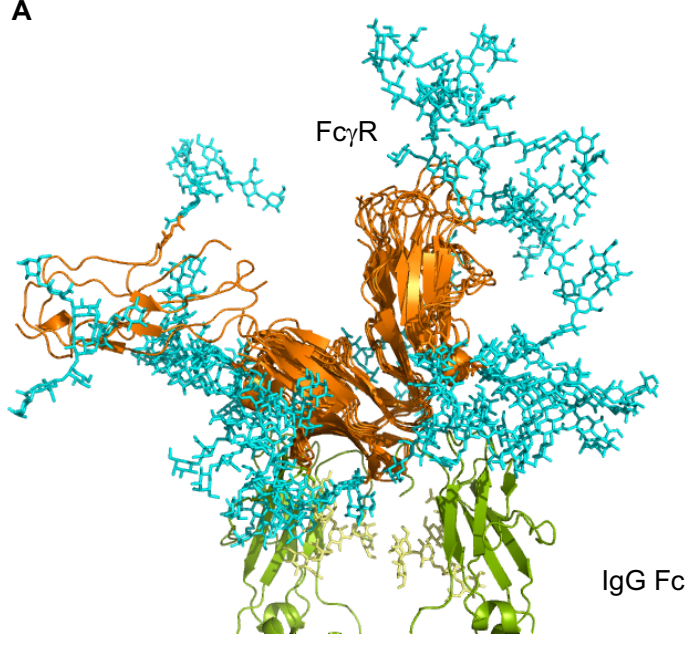

B

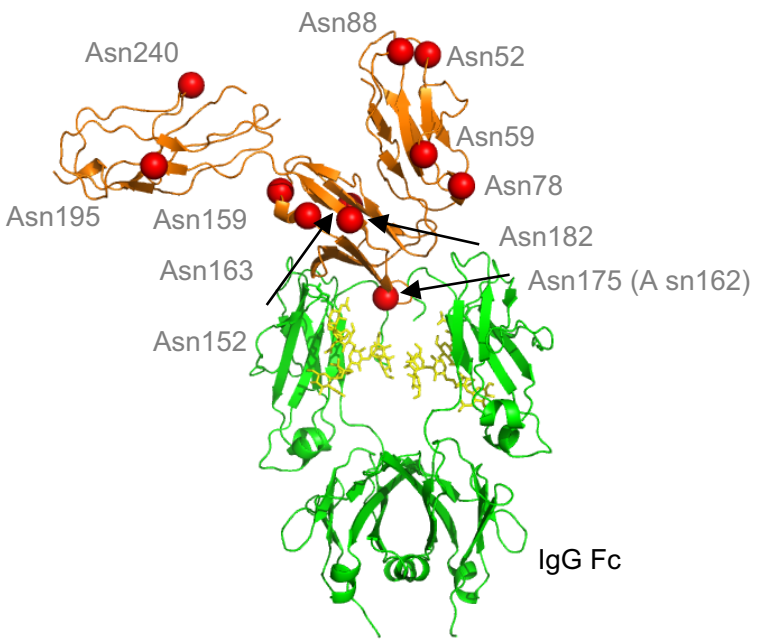

Figure 4 Human FcyRs show complex N-glycosylation in the protein ectodomain and around the lgG binding site.

Notes: (A) Structural overlay of FcyRs. FcyRs are very structurally homologous with the exception of the extra D3 domain in Fc $\gamma R$ I. Complexity of glycans (cyan) is shown and potential interactions with $\operatorname{lgG} \mathrm{Fc}$ and the $\operatorname{lgG} \mathrm{Fc}$ glycans. The glycan compositions modeled onto each N-glycosylation site for each FcyR are named according to the oxford notation (see https://glycobase.nibrt.ie/glycobase/show_nibrt.action) ${ }^{86}$ and are as follows: FcyRI: Asn 59 (Man 5), Asn 78 (FA2G2SI), Asn I52 (FA2GN2S2), Asn I59 (Man 6), Asn 163 (FA2G2), Asn 195 (FA2GIGNI), Asn 240 (FA2BG2). FcyRlla: Asn 64 (FA2G2SI), Asn I45 (FA2BG2). FcyRIlb: Asn 66 (FA2G2SI), Asn I47 (FA2BG2).

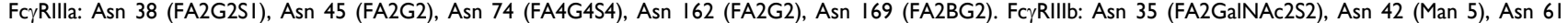
(FA2G2SI), Asn 7I (FA3G2), Asn I59 (FA2BGI), Asn I66 (FA2BG2). PDB accession numbers used to build the models were as follows: FcyRI: 4x4m, Fc $\gamma$ RIla: Ifcg, Fc $\gamma$ RIlb:

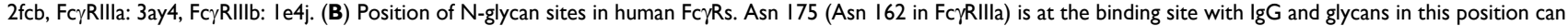
participate in carbohydrate-carbohydrate interactions. A number of other glycan sites are present close to the binding interface with lgG and glycans in this position can potentially participate in glycan-glycan interactions and glycan-protein interactions with lgG Fc. Structure is based on FcyRI (PDB: 4x4m). N-glycosylation sites are named for Fc $\gamma \mathrm{RI}$ using the UniprotKB numbering scheme.

Abbreviations: Fc $\gamma R$, Fc gamma receptor; IgG, immunoglobulin G; PDB, Protein Data Bank. 
undersialylated (Figure 2). Oligomannose structures are also present and vary depending on the receptor with the largest amount observed for Fc $\gamma$ RI (Figure 2). Very little information exists as to the natural glycosylation state of any of the receptors in healthy or disease states, and little information exists as to the glycosylation site occupancy for any of the natural receptors and only for recombinant Fc $\gamma \mathrm{RIIIa} .{ }^{47}$

\section{FcyRs as therapeutic targets and a role for glycosylation}

FcyRs mediate many of the biological functions of therapeutic Mabs, particularly when the induction of effector activities is desired. Manipulating the Fc glycan of Mabs is a successful strategy to prevent interaction with Fc $\gamma$ Rs when the activation of the immune system is not required for the efficacy of the antibody or is undesirable. In the primary mechanism of oncology Mabs such as rituximab and trastuzumab, Fc $\gamma$ RIIIa is targeted to induce ADCC. Glycoengineering of the antibody $\mathrm{Fc}$ region has proved to be a highly successful strategy to target and improve Fc $\gamma \mathrm{R}$ binding and $\mathrm{ADCC}$, and the nextgeneration glycoengineered afucosylated Mab Gazyva is now on the market. It is also worth noting that aglycosylated IgG variants with specific mutations in the Fc region have been shown to bind Fc $\gamma R$ I with equal or greater affinity than wild-type IgG, presenting an alternative therapeutic strategy. ${ }^{60}$ Various glycosylation modeling platforms have also added to our understanding of complex networks leading to specific glycoforms. ${ }^{61-65}$ Polymorphisms found in the extracellular domain of Fc $\gamma \mathrm{Rs}$ further add to their variability and complexity, in particular, the Val 158/Phe 158 polymorphism

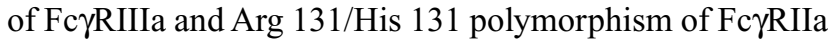
dictate how a patient responds to antibody therapy with the Val 158 and His 131 variants responding better to rituximab treatment in non-Hodgkins lymphoma. ${ }^{66,67}$ Furthermore, with detailed knowledge of the glycosylation of $\mathrm{Fc} \gamma \mathrm{Rs}$ in patients, there is the potential to manipulate and target an Fc $\gamma \mathrm{R}$ glycoprofile to improve the therapeutic effect. Prediction of how a patient will respond to antibody therapy or identification of biomarkers for nonresponders are important factors for developing a personalized medicine approach.

FcyR expression and regulation are important factors in antibody therapy for a range of clinical conditions. Receptor expression levels are shown to differ in patients with cancer, and the inhibitory FcyRIIb is shown to be upregulated in conditions such as malignant melanoma and lymphomas. ${ }^{68-71}$ Inhibitory receptor expression is also reported to be decreased on memory B-cells and plasma cells from patients with chronic inflammatory demyelinating neuropathy treated with IVIg, suggesting that in inflammatory or pro-inflammatory conditions Fc $\gamma \mathrm{R}$ activation prevails or is increased over inhibitory conditions. ${ }^{72}$ In inflammatory bowel disease and systemic lupus erythematosus, conditions characterized by chronic inflammation, Fc $\gamma$ RI upregulation has been reported. ${ }^{73,74}$ Higher expression

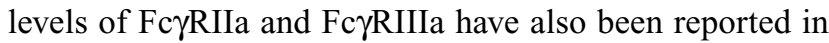
autoimmune conditions, and the anti-TNF Mab infliximab has been reported to decrease the expression of activating receptors. ${ }^{75}$ Viral and bacterial infections also influence the surface numbers of activating and inhibitory Fc $\gamma$ Rs, and bacterial components such as lipopolysaccharide increase the expression of Fc $\gamma$ RIII and Fc $\gamma$ RIV in mice ${ }^{76}$ and cytokines such as interferon- $\gamma$ can regulate or alter Fc $\gamma \mathrm{R}$ expression, particularly in viral infections such as HIV. ${ }^{77,78}$ In these cases, an antibody or combination therapy to block a particular receptor such as the inhibitory receptor in cancer or activating receptors in inflammation could prove to be an effective strategy by skewing the A/I ratio toward cellular activation or inhibition. Furthermore, there are many examples of cancerspecific glycosylation changes, which promote metastasis, survival and immune evasion. It is therefore likely that the glycosylation of Fc $\gamma$ Rs present on cancer cells such as non-Hodgkin lymphoma will be affected in a way that will prevent productive antibody interactions. It is also likely that cancer cells will negatively influence the glycosylation of Fc $\gamma$ Rs on cytotoxic cells, such as NK cells to inhibit productive antibody interactions and promote cancer cell survival. Immunotherapies can be improved with the knowledge of the glycosylation profiles of Fc $\gamma \mathrm{Rs}$ in healthy and disease states.

\section{Glycosylated Fc $\gamma$ Rs as therapeutics}

Targeting Fc $\gamma$ Rs with small molecule inhibitors or antireceptor Mabs is an attractive strategy to prevent immune complex-driven activation of effector cells, a major driver of inflammation and autoimmunity. Since the 1990s, soluble Fc $\gamma R$ s, formed by alternate splicing or proteolytic cleavage of the receptor ectodomain, have been identified in humans and mice and have been shown to inhibit B-cell proliferation and IgG production. ${ }^{79}$ Recombinant forms of the soluble ectodomains of activating receptors (FcyRI, Fc $\gamma R I I$ and

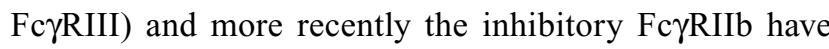
been used to perform a similar therapeutic anti-inflammatory role in humans with significant success. ${ }^{80-84}$ These soluble domains are believed to function as decoy receptors to bind IgG immune complexes, decrease the $\mathrm{A} / \mathrm{I}$ ratio and prevent inflammation and autoimmunity. ${ }^{85}$ Although these soluble Fc $\gamma$ Rs have low affinity (except Fc $\gamma R$ I) for IgG immune 
complexes, positive results in reducing inflammation have been shown in epidermolysis bullosa acquisita. ${ }^{80,84}$ In addition to the low-affinity nature of soluble Fc $\gamma \mathrm{Rs}$, another downside to their use as therapeutics is their relatively small size, ranging from 20 to $45 \mathrm{kDa}$ in their aglycosylated state (Table 1). This leads to difficulties such as rapid excretion in vivo. A possible mechanism to increase the size of the Fc $\gamma \mathrm{R}$ therapeutic is to use recombinant glycosylated forms made in cells such as CHO cells or HEK293 cells (Figure 2), as opposed to aglycosylated forms made in bacteria such as Escherichia coli. In addition to increasing the size of the therapeutic, the strategy of using glycosylated ectodomains has the added benefit of increasing the solubility of the receptor and may in addition help in the clearance of glycosylated FcyR immune complexes through interactions with lectins such as MBL on macrophages through phagocytosis. Glycosylated Fc $\gamma \mathrm{R}$ ectodomains have the potential to increase the clearance of immune complexes and further reduce inflammation through this glycosylated Fc $\gamma \mathrm{R}-$ lectin-based phagocytosis mechanism.

\section{Glycosylation of FcyRs: therapeutic prospects}

There is now clear evidence that Fc $\gamma \mathrm{R}$ glycosylation is an important factor in the interaction with therapeutic antibodies and could influence immune system activation or inhibition. ${ }^{40,43,47}$ This has important implications for how Mab-based therapeutics and fusion proteins are designed. However, little is known about the glycosylation of these receptors in their natural environment and until detailed information on how each receptor is glycosylated by different cells of the immune system in healthy and disease states is available, complete understanding of how therapeutic antibodies interact with the immune system to activate or inhibit will remain incomplete. Although important information is available, which shows that immune cells such as macrophages and monocytes bind and respond to IgG differentially, most of the detailed information on glycosylation and its influence on the IgG-Fc $\gamma \mathrm{R}$ interaction come from recombinant systems and receptors expressed in NS0, HEK293 and CHO cells. ${ }^{43-47}$ This information is valuable and shows that receptor glycosylation is cell type specific and influences the IgG-binding kinetics and indicates that cells of the immune system such as NK cells, macrophages, neutrophils and B-cells will also glycosylate in a cell type-specific manner, which can result in each cell responding differently to $\mathrm{IgG}$ and $\mathrm{IgG}$ immune complexes. The particular glycans that the cell expresses on the Fc $\gamma \mathrm{R}$, based on its own glycosylation machinery, can determine the antibody response and it is conceivable that in a state of inhibition or inactivation specific glycans can be expressed on the $\mathrm{Fc} \gamma \mathrm{R}$ that can prevent a productive interaction with immune complexes or decrease the affinity for antibody. Conversely, in a state of inflammation or activation, different glycans can be expressed on the FcyR to promote a positive antibody interaction and induce effector responses. Fc $\gamma R$ glycosylation can therefore be used as a mechanism by the immune system to fine-tune the antibody response. In inflammatory and autoimmune conditions, for example, Fc $\gamma R$ s found on macrophages, monocytes and neutrophils are potentially glycosylated in a manner that facilitates excessive interaction with antibodies, immune complexes or self-antigens that promote inflammation and autoimmunity. In addition, in healthy states, glycans can potentially be used by Fc $\gamma R s$ to inhibit or decrease antibody engagement, downregulate immune responses and prevent inflammation and autoimmunity. Glycans on FcyRs can therefore be used to alter the balance between activation and inhibition in a glycosylation-mediated control mechanism. In addition, until this detailed glycan information is available, the glycosylation of Fc $\gamma$ Rs cannot be fully understood with the aim of manipulating or optimizing therapeutics based on the glycosylation state of the Fc $\gamma$ R. There is the potential to design therapeutics to specifically target known Fc $\gamma \mathrm{R}$ glycoforms in a particular disease such as cancer or inflammatory or autoimmune conditions, which are known to promote or inhibit productive antibody interactions. Information exists that monocyte Fc $\gamma$ RIIIa does not contain high-mannose-type glycans whereas NK cell Fc $\gamma$ RIIIa does, and this can explain the lower affinity of the monocyte/macrophage glycoform. ${ }^{45}$ This information, together with further detailed glycan data, can be exploited to design therapeutics to differentially bind specific Fc $\gamma R$ glycoforms such as an Mab with higher affinity for the high-mannose-type glycoform of macrophages if antibody-dependent phagocytosis is desired.

Detailed knowledge of Fc $\gamma R$ glycobiology in inflammatory and autoimmune conditions and the availability of glycan information will allow for a deeper and more comprehensive knowledge and understanding of these conditions and how to treat them, the type of antibody isotype, glycoform or fusion protein to design and a much more targeted approach to an individual or condition. This raises the possibility of a personalized medicine approach, whereby patient's Fc $\gamma \mathrm{R}$ glycoforms could be determined and the therapeutic approach tailored to suit a particular person. A patient's Fc $\gamma$ Rs, including polymorphisms and glycoprofiles, could be used to predict the efficacy of a therapeutic Mab and identify responders and nonresponders to expensive and potentially dangerous biological therapies. There is evidence in the literature that 
the glycans present on Fc $\gamma$ Rs made in recombinant systems can modulate the binding interaction with antibody. ${ }^{43}$ By knowing the natural glycoprofiles of these receptors, the interaction of therapeutic Mabs with their target cells such as NK cells in cancer treatment can be better understood and the clinical outcome can be better predicted.

Finally, the biopharmaceutical industry typically uses biophysical techniques such as surface plasmon resonance and recombinant forms of Fc $\gamma$ Rs expressed in NS0, HEK293 or $\mathrm{CHO}$ cells to determine the interactions of therapeutic antibodies with Fc $\gamma$ Rs, affinity constants and kinetic parameters. While these systems provide valuable information, the downside to this approach is that the physiological system is not fully represented and these recombinant receptors do not adequately predict the outcome of an antibody therapy or the interactions of a therapeutic antibody with cells and FcyRs of the immune system, partly because the Fc $\gamma$ Rs used in these analyses are glycosylated differently to the Fc $\gamma$ Rs of the immune system. There are examples in the literature, which show that the interaction kinetics of therapeutic antibodies is different in biophysical experiments depending on the source of the receptor and its glycosylation pattern. ${ }^{47,50}$ By understanding the glycosylation of the natural FcyRs, there is the potential to design and use recombinant forms of the receptors, which have glycoprofiles that physiologically resemble the natural Fc $\gamma \mathrm{R}$ s in biophysical evaluations to provide more accurate affinity determinations, analysis of the interaction and ultimately predictions of the physiological outcome of the antibody therapy.

\section{Acknowledgment}

The authors acknowledge the funding sources such as the EU Initial Training Network (Project No 608381) and Science Foundation Ireland (Grant No SFI-13/SP SSPC/I2893) for supporting this work.

\section{Disclosure}

The authors report no conflicts of interest in this work.

\section{References}

1. Alzari PM, Lascombe MB, Poljak RJ. Three-dimensional structure of antibodies. Annu Rev Immunol. 1988;6:555-580.

2. Burton DR, Woof JM. Human antibody effector function. Adv Immunol. 1992;51:1-84.

3. Edelman GM, Cunningham BA, Gall WE, Gottlieb PD, Rutishauser U, Waxdal MJ. The covalent structure of an entire gammaG immunoglobulin molecule. Proc Natl Acad Sci US A. 1969;63(1):78-85.

4. Porter RR. Structural studies of immunoglobulins. Science. 1973; 180(4087):713-716.

5. Kohler G, Milstein C. Continuous cultures of fused cells secreting antibody of predefined specificity. Nature. 1975;256(5517):495-497.

6. Chung $\mathrm{CH}$, Mirakhur B, Chan E, et al. Cetuximab-induced anaphylaxis and IgE specific for galactose-alpha-1,3-galactose. $N$ Engl J Med. 2008;358(11):1109-1117.
7. Arnold JN, Wormald MR, Sim RB, Rudd PM, Dwek RA. The impact of glycosylation on the biological function and structure of human immunoglobulins. Annu Rev Immunol. 2007;25:21-50.

8. Jefferis R. Glycosylation as a strategy to improve antibody-based therapeutics. Nat Rev Drug Discov. 2009;8(3):226-234.

9. Jefferis R, Lund J, Goodall M. Recognition sites on human IgG for Fc gamma receptors: the role of glycosylation. Immunol Lett. 1995;44(2-3): 111-117.

10. Reusch D, Tejada ML. Fc glycans of therapeutic antibodies as critical quality attributes. Glycobiology. 2015;25(12):1325-1334.

11. Krapp S, Mimura Y, Jefferis R, Huber R, Sondermann P. Structural analysis of human IgG-Fc glycoforms reveals a correlation between glycosylation and structural integrity. J Mol Biol. 2003;325(5):979-989.

12. Kaneko Y, Nimmerjahn F, Ravetch JV. Anti-inflammatory activity of immunoglobulin G resulting from Fc sialylation. Science. 2006;313(5787):670-673.

13. Okazaki A, Shoji-Hosaka E, Nakamura K, et al. Fucose depletion from human IgG1 oligosaccharide enhances binding enthalpy and association rate between IgG1 and FcgammaRIIIa. J Mol Biol. 2004;336(5): 1239-1249.

14. Iida $\mathrm{S}$, Misaka $\mathrm{H}$, Inoue $\mathrm{M}$, et al. Nonfucosylated therapeutic IgG1 antibody can evade the inhibitory effect of serum immunoglobulin $G$ on antibody-dependent cellular cytotoxicity through its high binding to FcgammaRIIIa. Clin Cancer Res. 2006;12(9):2879-2887.

15. Satoh M, Iida S, Shitara K. Non-fucosylated therapeutic antibodies as next-generation therapeutic antibodies. Expert Opin Biol Ther. 2006;6(11):1161-1173.

16. Shields RL, Lai J, Keck R, et al. Lack of fucose on human IgG1 N-linked oligosaccharide improves binding to human Fcgamma RIII and antibodydependent cellular toxicity. J Biol Chem. 2002;277(30):26733-26740.

17. Niwa R, Natsume A, Uehara A, et al. IgG subclass-independent improvement of antibody-dependent cellular cytotoxicity by fucose removal from Asn297-linked oligosaccharides. J Immunol Methods. 2005;306(1-2): 151-160.

18. Natsume A, Wakitani M, Yamane-Ohnuki N, et al. Fucose removal from complex-type oligosaccharide enhances the antibody-dependent cellular cytotoxicity of single-gene-encoded bispecific antibody comprising of two single-chain antibodies linked to the antibody constant region. $J$ Biochem. 2006;140(3):359-368.

19. Walsh G. Biopharmaceutical benchmarks 2014. Nat Biotechnol. 2014;32(10):992-1000.

20. Ecker DM, Jones SD, Levine HL. The therapeutic monoclonal antibody market. MAbs. 2015;7(1):9-14.

21. Sondermann P, Pincetic A, Maamary J, Lammens K, Ravetch JV. General mechanism for modulating immunoglobulin effector function. Proc Natl Acad Sci U S A. 2013;110(24):9868-9872.

22. Crispin M, Yu X, Bowden TA. Crystal structure of sialylated IgG Fc: implications for the mechanism of intravenous immunoglobulin therapy. Proc Natl Acad Sci U S A. 2013;110(38):E3544-E3546.

23. Liu L. Antibody glycosylation and its impact on the pharmacokinetics and pharmacodynamics of monoclonal antibodies and Fc-fusion proteins. J Pharm Sci. 2015;104(6):1866-1884.

24. Liu L, Gomathinayagam S, Hamuro L, et al. The impact of glycosylation on the pharmacokinetics of a TNFR2:Fc fusion protein expressed in glycoengineered Pichia pastoris. Pharm Res. 2013;30(3): 803-812.

25. Anthony RM, Nimmerjahn F, Ashline DJ, Reinhold VN, Paulson JC, Ravetch JV. Recapitulation of IVIG anti-inflammatory activity with a recombinant IgG Fc. Science. 2008;320(5874):373-376.

26. Kanda Y, Yamada T, Mori K, et al. Comparison of biological activity among nonfucosylated therapeutic IgG1 antibodies with three different N-linked Fc oligosaccharides: the high-mannose, hybrid, and complex types. Glycobiology. 2007;17(1):104-118.

27. Goetze AM, Liu YD, Zhang Z, et al. High-mannose glycans on the Fc region of therapeutic IgG antibodies increase serum clearance in humans. Glycobiology. 2011;21(7):949-959.

28. Daeron M. Fc receptor biology. Annu Rev Immunol. 1997;15: 203-234. 
29. Bruhns P, Iannascoli B, England P, et al. Specificity and affinity of human Fcgamma receptors and their polymorphic variants for human IgG subclasses. Blood. 2009;113(16):3716-3725.

30. Powell MS, Hogarth PM. Fc receptors. Adv Exp Med Biol. 2008; 640:22-34.

31. Ravetch JV, Bolland S. IgG Fc receptors. Annu Rev Immunol. 2001; 19:275-290

32. Sondermann P, Kaiser J, Jacob U. Molecular basis for immune complex recognition: a comparison of Fc-receptor structures. J Mol Biol. 2001; 309(3):737-749.

33. Hulett MD, Hogarth PM. Molecular basis of Fc receptor function. $A d v$ Immunol. 1994;57:1-127.

34. Nimmerjahn F, Ravetch JV. Fcgamma receptors as regulators of immune responses. Nat Rev Immunol. 2008;8(1):34-47.

35. Koene HR, Kleijer M, Algra J, Roos D, von dem Borne AE, de Haas M. Fc gammaRIIIa-158V/F polymorphism influences the binding of IgG by natural killer cell Fc gammaRIIIa, independently of the Fc gammaRIIIa-48L/R/H phenotype. Blood. 1997;90(3):1109-1114.

36. Wu J, Edberg JC, Redecha PB, et al. A novel polymorphism of FcgammaRIIIa (CD16) alters receptor function and predisposes to autoimmune disease. J Clin Invest. 1997;100(5):1059-1070.

37. Nieto A, Caliz R, Pascual M, Mataran L, Garcia S, Martin J. Involvement of Fcgamma receptor IIIA genotypes in susceptibility to rheumatoid arthritis. Arthritis Rheum. 2000;43(4):735-739.

38. Duits AJ, Bootsma H, Derksen RH, et al. Skewed distribution of IgG Fc receptor IIa (CD32) polymorphism is associated with renal disease in systemic lupus erythematosus patients. Arthritis Rheum. 1995;38(12):1832-1836.

39. Hayes JM, Cosgrave EF, Struwe WB, et al. Glycosylation and Fc receptors. Curr Top Microbiol Immunol. 2014;382:165-199.

40. Ferrara C, Grau S, Jager C, et al. Unique carbohydrate-carbohydrate interactions are required for high affinity binding between FcgammaRIII and antibodies lacking core fucose. Proc Natl Acad Sci U S A. 2011; 108(31):12669-12674.

41. Ferrara C, Stuart F, Sondermann P, Brunker P, Umana P. The carbohydrate at FcgammaRIIIa Asn-162. An element required for high affinity binding to non-fucosylated IgG glycoforms. J Biol Chem. 2006;281(8): 5032-5036.

42. Shibata-Koyama M, Iida S, Okazaki A, et al. The N-linked oligosaccharide at Fc gamma RIIIa Asn-45: an inhibitory element for high Fc gamma RIIIa binding affinity to IgG glycoforms lacking core fucosylation. Glycobiology. 2009;19(2):126-134.

43. Hayes JM, Frostell A, Cosgrave EF, et al. Fc gamma receptor glycosylation modulates the binding of IgG glycoforms: a requirement for stable antibody interactions. J Proteome Res. 2014;13(12):5471-5485.

44. Edberg JC, Barinsky M, Redecha PB, Salmon JE, Kimberly RP. Fc gamma RIII expressed on cultured monocytes is a N-glycosylated transmembrane protein distinct from Fc gamma RIII expressed on natural killer cells. J Immunol. 1990;144(12):4729-4734.

45. Edberg JC, Kimberly RP. Cell type-specific glycoforms of Fc gamma RIIIa (CD16): differential ligand binding. J Immunol. 1997;159(8): 3849-3857.

46. Kimberly RP, Tappe NJ, Merriam LT, et al. Carbohydrates on human Fc gamma receptors. Interdependence of the classical IgG and nonclassical lectin-binding sites on human Fc gamma RIII expressed on neutrophils. J Immunol. 1989;142(11):3923-3930.

47. Zeck A, Pohlentz G, Schlothauer T, Peter-Katalinic J, Regula JT. Cell type-specific and site directed N-glycosylation pattern of FcgammaRIIIa. J Proteome Res. 2011;10(7):3031-3039.

48. Sondermann P, Huber R, Oosthuizen V, Jacob U. The 3.2-A crystal structure of the human IgG1 Fc fragment-Fc gammaRIII complex. Nature. 2000;406(6793):267-273.

49. Radaev S, Motyka S, Fridman WH, Sautes-Fridman C, Sun PD. The structure of a human type III Fcgamma receptor in complex with Fc. $J$ Biol Chem. 2001;276(19):16469-16477.

50. Cosgrave EF, Struwe WB, Hayes JM, Harvey DJ, Wormald MR, Rudd PM. N-linked glycan structures of the human Fcgamma receptors produced in NS0 cells. J Proteome Res. 2013;12(8):3721-3737.
51. Sondermann P, Jacob U, Kutscher C, Frey J. Characterization and crystallization of soluble human Fc gamma receptor II (CD32) isoforms produced in insect cells. Biochemistry. 1999;38(26):8469-8477.

52. Powell MS, Barton PA, Emmanouilidis D, et al. Biochemical analysis and crystallisation of Fc gamma RIIa, the low affinity receptor for IgG. Immunol Lett. 1999;68(1):17-23.

53. Takahashi N, Cohen-Solal J, Galinha A, Fridman WH, Sautes-Fridman C, Kato K. N-glycosylation profile of recombinant human soluble Fcgamma receptor III. Glycobiology. 2002;12(8):507-515.

54. Takahashi N, Yamada W, Masuda K, et al. N-glycan structures of a recombinant mouse soluble Fcgamma receptor II. Glycoconj J. 1998;15(9):905-914.

55. Galon J, Robertson MW, Galinha A, et al. Affinity of the interaction between Fc gamma receptor type III (Fc gammaRIII) and monomeric human IgG subclasses. Role of Fc gammaRIII glycosylation. Eur $J$ Immunol. 1997;27(8):1928-1932.

56. Allen JM, Seed B. Isolation and expression of functional high-affinity Fc receptor complementary DNAs. Science. 1989;243(4889):378-381.

57. Harrison PT, Allen JM. High affinity IgG binding by FcgammaRI (CD64) is modulated by two distinct IgSF domains and the transmembrane domain of the receptor. Protein Eng. 1998;11(3):225-232.

58. Lu J, Chu J, Zou Z, Hamacher NB, Rixon MW, Sun PD. Structure of FcgammaRI in complex with $\mathrm{Fc}$ reveals the importance of glycan recognition for high-affinity IgG binding. Proc Natl Acad Sci U SA . 2015;112(3):833-838.

59. Lu J, Ellsworth JL, Hamacher N, Oak SW, Sun PD. Crystal structure of Fcgamma receptor I and its implication in high affinity gammaimmunoglobulin binding. J Biol Chem. 2011;286(47):40608-40613.

60. Jung ST, Reddy ST, Kang TH, et al. Aglycosylated IgG variants expressed in bacteria that selectively bind FcgammaRI potentiate tumor cell killing by monocyte-dendritic cells. Proc Natl Acad Sci US A. 2010;107(2):604-609.

61. Krambeck FJ, Betenbaugh MJ. A mathematical model of N-linked glycosylation. Biotechnol Bioeng. 2005;92(6):711-728.

62. Umana P, Bailey JE. A mathematical model of N-linked glycoform biosynthesis. Biotechnol Bioeng. 1997;55(6):890-908.

63. McDonald AG, Hayes JM, Bezak T, et al. Galactosyltransferase 4 is a major control point for glycan branching in N-linked glycosylation. J Cell Sci. 2014;127(pt 23):5014-5026.

64. McDonald AG, Tipton KF, Davey GP. A knowledge-based system for display and prediction of O-glycosylation network behaviour in response to enzyme knockouts. PLoS Comput Biol. 2016;12(4):e1004844.

65. McDonald AG, Hayes JM, Davey GP. Metabolic flux control in glycosylation. Curr Opin Struct Biol. 2016;40:97-103.

66. Weng WK, Levy R. Two immunoglobulin $\mathrm{G}$ fragment $\mathrm{C}$ receptor polymorphisms independently predict response to rituximab in patients with follicular lymphoma. J Clin Oncol. 2003;21(21):3940-3947.

67. Cartron G, Dacheux L, Salles G, et al. Therapeutic activity of humanized anti-CD20 monoclonal antibody and polymorphism in IgG Fc receptor FcgammaRIIIa gene. Blood. 2002;99(3):754-758.

68. Cassard L, Cohen-Solal JF, Fournier EM, et al. Selective expression of inhibitory Fcgamma receptor by metastatic melanoma impairs tumor susceptibility to IgG-dependent cellular response. Int J Cancer. 2008;123(12):2832-2839.

69. Cassard L, Cohen-Solal JF, Galinha A, et al. Modulation of tumor growth by inhibitory $\mathrm{Fc}$ (gamma) receptor expressed by human melanoma cells. J Clin Invest. 2002;110(10):1549-1557.

70. Callanan MB, Le Baccon P, Mossuz P, et al. The IgG Fc receptor, FcgammaRIIB, is a target for deregulation by chromosomal translocation in malignant lymphoma. Proc Natl Acad Sci US A. 2000;97(1):309-314.

71. Camilleri-Broet S, Cassard L, Broet P, et al. FcgammaRIIB is differentially expressed during B cell maturation and in B-cell lymphomas. Br J Haematol. 2004;124(1):55-62.

72. Tackenberg B, Jelcic I, Baerenwaldt A, et al. Impaired inhibitory Fcgamma receptor IIB expression on B cells in chronic inflammatory demyelinating polyneuropathy. Proc Natl Acad Sci USA. 2009;106(12): 4788-4792.

73. Li Y, Lee PY, Sobel ES, et al. Increased expression of FcgammaRI/ CD64 on circulating monocytes parallels ongoing inflammation and nephritis in lupus. Arthritis Res Ther. 2009;11(1):R6. 
74. Tillinger W, Jilch R, Jilma B, et al. Expression of the high-affinity IgG receptor FcRI (CD64) in patients with inflammatory bowel disease: a new biomarker for gastroenterologic diagnostics. Am J Gastroenterol. 2009;104(1):102-109.

75. Belostocki K, Park MS, Redecha PB, Masuda E, Salmon JE, Pricop L. FcgammaRIIa is a target for modulation by TNFalpha in human neutrophils. Clin Immunol. 2005;117(1):78-86.

76. Lunnon K, Teeling JL, Tutt AL, Cragg MS, Glennie MJ, Perry VH. Systemic inflammation modulates Fc receptor expression on microglia during chronic neurodegeneration. J Immunol. 2011;186(12):7215-7224.

77. Dugast AS, Tonelli A, Berger CT, et al. Decreased Fc receptor expression on innate immune cells is associated with impaired antibody-mediated cellular phagocytic activity in chronically HIV-1 infected individuals. Virology. 2011;415(2):160-167.

78. Capsoni F, Minonzio F, Ongari AM, et al. Fc receptors expression and function in mononuclear phagocytes from AIDS patients: modulation by IFN-gamma. Scand J Immunol. 1994;39(1):45-50.

79. de Haas M, Kleijer M, Minchinton RM, Roos D, von dem Borne AE Soluble Fc gamma RIIIa is present in plasma and is derived from natural killer cells. J Immunol. 1994;152(2):900-907.
80. Werwitzke S, Trick D, Sondermann P, et al. Treatment of lupus-prone NZB/NZW F1 mice with recombinant soluble Fc gamma receptor II (CD32). Ann Rheum Dis. 2008;67(2):154-161.

81. Ellsworth JL, Hamacher N, Harder B, et al. Recombinant soluble human FcgammaR1A (CD64A) reduces inflammation in murine collageninduced arthritis. J Immunol. 2009;182(11):7272-7279.

82. Ellsworth JL, Maurer M, Harder B, et al. Targeting immune complexmediated hypersensitivity with recombinant soluble human FcgammaRIA (CD64A). J Immunol. 2008;180(1):580-589.

83. Magnusson SE, Andren M, Nilsson KE, Sondermann P, Jacob U, Kleinau $\mathrm{S}$. Amelioration of collagen-induced arthritis by human recombinant soluble FcgammaRIIb. Clin Immunol. 2008;127(2):225-233.

84. Iwata H, Pipi E, Mockel N, et al. Recombinant soluble CD32 suppresses disease progression in experimental epidermolysis bullosa acquisita. J Invest Dermatol. 2015;135(3):916-919.

85. Nimmerjahn F. Translating inhibitory Fc receptor biology into novel therapeutic approaches. J Clin Immunol. 2016;36(suppl 1):83-87.

86. Campbell MP, Royle L, Radcliffe CM, Dwek RA, Rudd PM. GlycoBase and autoGU: tools for HPLC-based glycan analysis. Bioinformatics. 2008;24(9):1214-1216.
Journal of Inflammation Research

\section{Publish your work in this journal}

The Journal of Inflammation Research is an international, peer-reviewed open access journal that welcomes laboratory and clinical findings on the molecular basis, cell biology and pharmacology of inflammation including original research, reviews, symposium reports, hypothesis formation and commentaries on: acute/chronic inflammation; mediators of

\section{Dovepress}

inflammation; cellular processes; molecular mechanisms; pharmacology and novel anti-inflammatory drugs; clinical conditions involving inflammation. The manuscript management system is completely online and includes a very quick and fair peer-review system. Visit http://www.dove press.com/testimonials.php to read real quotes from published authors. 